Dept, of Food Hygiene,

Faculty of Vet. Med., Assiut University.

Head of Dept. Prof. Dr. A.A. Ismail.

\title{
OCCURRENCE OF SALMONELLA AMONG MARKET CALVES IN ASSIUT PROVINCE
}

(With 2 Tables)

By

\section{F.A. AHMED; M.A. SOBEIH and AMANI G. THABIT (Received at 2/5/1989)}

\author{
دراسح عن تواجد ميكروب السالمونهيلا فى العجول

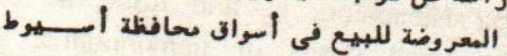

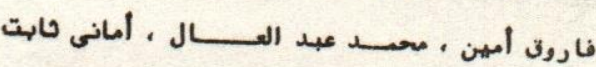

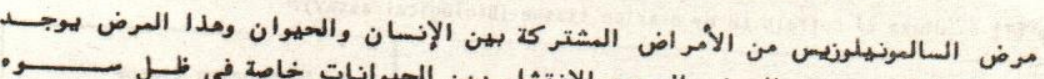

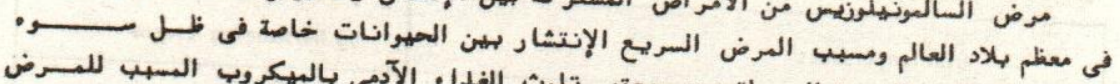

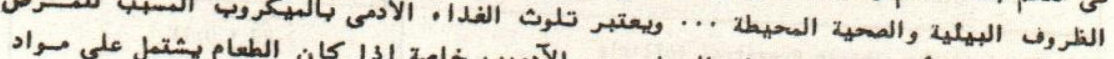

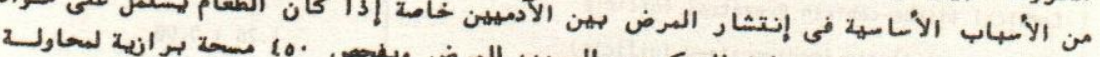

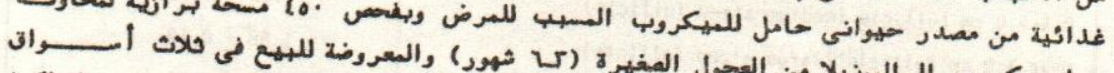

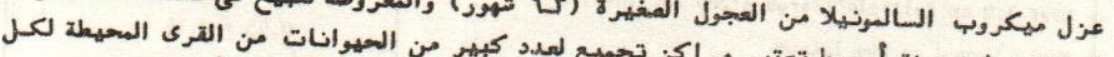

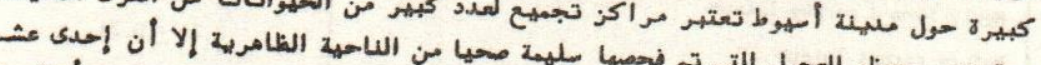

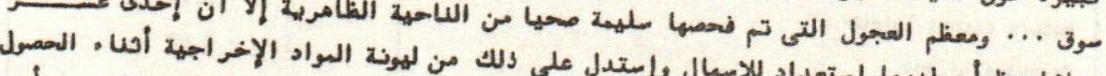

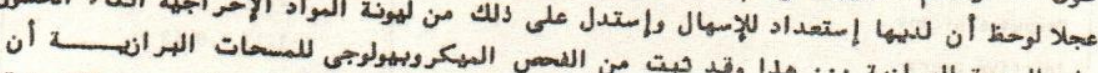

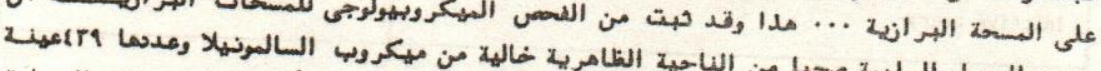

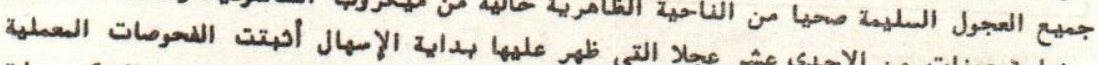

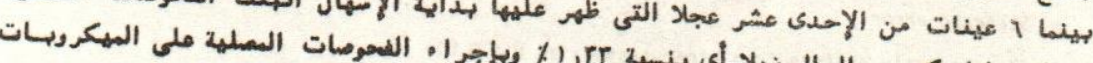

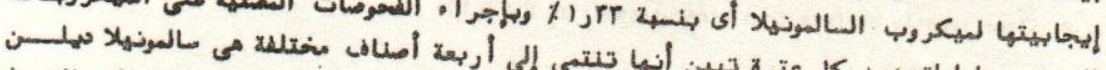

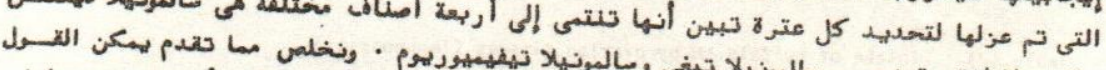

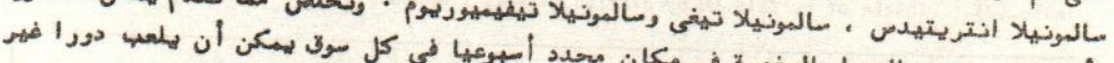

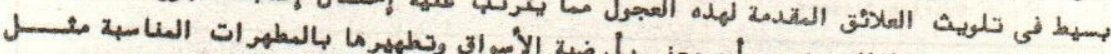

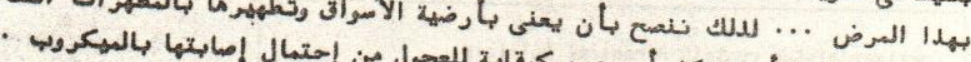

\section{SUMMARY}

Four hundred and fifty rectal swabs were collected from apparently healthy market calves of age 3 up to 6 months offered for sale in three large animal markets arround Assiut City; 150 samples were collected from each of EL-Maasara; Mankabad and EI-
Wasta.

* Dept. of Bacteriology, Fauclty of Med., Assiut Univ.

Assiut Vet.Med.J. Vol. 22, No. 43, 1989. 


\section{HODA HATEM, et al.}

Osteen, K.G.; Anderson, L.D.; Reichert, L.E. Jr. and Channing, C.P. (1985): Follicular fluid modulation of functional LH receptor induction in pig granulosa cells. J. Reprod. Fert. 74, 707-418.

Schuurs, A.H.W.M. (1969): Agglutination inhibition reactions for the determination of gonadotrophin-Karalinske symposia in research method in reproductive endocrinology 1st symposium, immunoassay of gonadotrophins. Shemesh, M. (1979): In bovine follicles. J. Endocr. 82: 27-31.

syrithesis in bovissay of luteinizing hormones. Nature, 185: 321.

Soliman, F.A. (1960): Assay of luteinizing hor Vaitukaitis, J.; Robbins, with small doses of immunogens. J. Cli. Endocrinology \& Metab. specific antis
33: $988-991$.

Table (1): Intake of buffalo LH by ovarian tissue (Biological assay)

\begin{tabular}{|l|c|}
\hline \multicolumn{1}{|c|}{ Uvarian tissues } & Ug hormone/mg tissue \\
\hline Cortical tissue contain Preantral follicle & $1.23 \pm 0.11$ \\
$0.5-1.0 \mathrm{~cm}$ fullicle (medium sized fullicle) & $1.28 \pm 0.00$ \\
Over $1.0 \mathrm{~cm}$ follicle (large sized follicle) & $1.88^{*} \pm 0.19$ \\
Newly formed corpus luteum & $0.93 \pm 0.16$ \\
Mature corpus luteum & $0.75 \pm 0.24$ \\
Corpus albicans & $1.41 \pm 0.00$ \\
Inactive ovary & $1.13 \pm 0.13$ \\
\hline
\end{tabular}

\pm Standard error

- Significantly differs from other tissues at $P<0.01$

Table (2): Intake of buffalo LH by ovarian tissues (Immunoassay)

\begin{tabular}{|l|c|}
\hline \multicolumn{1}{|c|}{ Ovarian tissues } & Ug intake $\mathrm{mg} / \mathrm{tissue}$ \\
\hline Cortical tissue contain Preantral follicle & $0.60 \pm 0.10$ \\
$0.5-1.0 \mathrm{~cm}$ fillicle (medium sized follicle) & $0.95 \pm 0.31$ \\
Uvei $1.0 \mathrm{~cm}$ lullicle (large sized follicle) & $1.30 \pm 0.20$ \\
Mewly formed corpus luteum & $0.23 \pm 0.01$ \\
Mature corpus luteun & $0.30 \pm 0.06$ \\
Corpus albicans & $0.28 \pm 0.07$ \\
Inactive ovary & $0.55 \pm 0.16$ \\
\hline
\end{tabular}

\footnotetext{
\pm Standard error

* Significantly differs fron other tissues at $P<0.01$.
} 


\section{F.A. AHMED, et al.}

Most of the examined calves were apparently healthy, except eleven calves which showed a tendency to diarrhoea 4 calves in EI-Wasta; 6 calves in EI-Maasara and the last one in Mankabad. Only 6(1.33\%) calves were proved to harbour Salmonella in their rectal swabs and they all had the tendency to be diarrhoetic. The isolated strains are belonged to four serological types S.dublin (2 strains, 0.44\%); S.enteritidis (2 strains, 0.44\%); S.typhi (1 strain, 0.22\%) and S.typhimurium (1 strain, $0.22 \%$ ).

\section{INTRODUCTION}

Salmonellosis is probably the most commonly occurring zoonotic disease in most countries of the world. This is primarly due to ubiquitous nature of the organism and the ease by which it is transmitted among animals under natural conditions especially if sanitation is not adequate. It is an accepted fact that foods of animal origin are the main source of Salmonella infections among human beings, and many animal species serve as reservoirs of these organisms.

Salmonellae are frequently found in clinically healthy farm animals (MORGAN et al., 1969). Studies on large groups of cattle indicated that the percentage of such latent infections was about 13\% in the United States and about 14\% in Nether Land (ROTHENBACKER, 1965).

The carrier state in apparently healthy calves appears to be quite variable. Some investigators isolated Salmonella in high incidence; ARROYO and BOLANOS (1960) examined several sites in Costa Rica and found that 13.3 percent of the cattle were infected with Salmonella even though they showed no signs of disease. KEULEN and HOFSTRA (1964) in Holand carried out an investigation to determine the percentage of calves infected with Salmonella it was 14.3\%. DALEEL and FOROST (1967) found Salmonella species in $7.8 \%$ of the examined apparently healthy calves. In another survey made by EDEL and KAMPELMACHER (1970) $14.1 \%$ of calves were found to carry Salmonellae.

The strains of Salmonella frequently isolated from both diseased and helathy farm animais included different serotypes as S.typhimurium; S.derby; S.dublin; S.oranienburg; S.java; S.choleraesuis; S.anatum; S.newington; S.infants; S.stanley; S.abeny; S.chester; S.typhi; S.enteritidis and S.meleagridis (MINER, et al., 1967). A number of epidemics had been observed in human population which were caused by most of Salmonella serotypes frequently found in farm animals (Nottingham and Urselmann, 1961).

Not all infected cattle with Salmonella excrete the organism in their faeces, but do often excrete it intermittently. However, detection of infected animals by demonstrating Salmonella organism in excreta is the only reliable method available (HEARD, et alo, 1972).

The investigation was undertaken to study the occurrence of Salmonella in the intestinal contents of the 450 apparently healthy calves offered for sale in markets.

Assiut Vet.Med]. Vol. 22, No. 43, 1989. 


\section{SALMONELLA AMONG MARKET CALVES}

The purpose of this investigation was to determine the prevalence of Salmonella serotypes in market calves and to discuss their importance from the veterinary public health point of view.

\section{MATERIAL and METHODS}

450 rectal swabs were collected from inarket calves apparently healthy of age3 up to 6 months, using sterile cotton/wood swabs in sterile test tubes. Samples were collected from three large animal saleyards which were choosen as a major animal collection centers to which large number of animals used to come out from many villages arround Assiut City, to be offered for sale. These markets are located in El-Maasara; Mankabad and El-Wasta.

For practical purposes an average of fifty rectal swabs per week were obtained for laboratory examination. Apparently healthy calves, as well as, those manifesting digestive problem, e.g. diarrhosa or sick appearance were swabed. The apparently healthy group were selected at random.

The samples collected are 150 rectal swabs from each of the 3 market as shown in table (1).

The anal region of each apparently healthy calf as well as, the diarrhoetic one was first cleaned with a piece of cotton soaked in alcohol preior to swabbing in order to minimize contamination. The swab was then placed in a test tubes containing $5 \mathrm{ml}$. physiological salin as transport medium and conveyed to the laboratory as soon as possible with a minimum delay.

Bacteriological examination of the specimens followed enteric bacteriological procedures. The swab and saline suspension were pre-enriched using selenite broth and incubated at $37^{\circ} \mathrm{C}$. for $18 \mathrm{hrs}$. Then differential plates of MacConkey; S.S. agar and Brilliant green agar were streaked and aerobically incubated at $37^{\circ} \mathrm{C}$. for 24 hrs.

Suspected Salmonella isolates were identified according the standard biochemical tests of the enterobacteriaceae adopted by (Edward and Ewing, 1972; Cruikshank, et al., 1975 and Bailey \& Scott, 1978).

Salmonella strains were tested against "O" Group antisera. For complete identification.

\section{RESULTS AND DISCUSSION}

The results tablutated in tables ( 1 \& 2) show that.

439 calves, which were apparently healthy without any tendency to diarrhoea were free from Salmonella. The rest eleven calves which were apparently healthy showed slight soft faeces (enteric calves).

Assiut Vet.Med.J. Vol. 22, No. 43, 1989. 


\section{F.A. AHMED, et al.}

From table (1) it is clear that, not all enteric calves harboured Salmonella the same percentage in EI of Mankabad was positive for Salmonell cases out of 4 calves), while the enteric calf

In an investigation made $0.5 \%$ of calves. This figure Salmonella isolation was made from only (1957) who examined calves and ith the data obtained by KAMPELMACHER In Britain only 0.4 percent carriers modes showed negative results (SMITH, found and examinations of mesenteric lymph faecal samples swabs from five (1969) examined 675 of 391 meat samples there was ed -investigations showing low incidence salmonella infection. The aforemantionas our incidence are in agreement with The latter reported that only one specimen results recorded by HEARD et al. (1972). from calves, was found to be recorded that, a variable proportion for Salmonella. Moreover, SHARMA et al. (1972) calves.

Since some investigators isolated Salmonella in higher incidence as (ARROYO \& BOLANOS, 1960; KEULEN \& HOFSTRA, 1964; DALEEL \& FROST, 1967 and (ARROYO

was isolated from to Salmonella dublin and Salmonella enteritidis typhimurium was isolated from one calf a focus of infection among both human similarly isolated by DEDIE and SCHOENE (1974).

The main possible cause suggested to be the source of infection is ingestion of contaminated pastures (RANKIN \& TAYLOR, 1969; JACK \& HEPPER, 1969 and RANKIN
\& BURROW, 1970).

From the veterinary public health point of veiw; reserved limited areas in the saleyard (markets) which is commonly reserved for calves offered for sale weekly clinically healthy important role in spreading the infection in aquired way, among the and disinfect these areas of aggrigation of the mation lime before the time cycle of aquired infection calves every two weeks in order to break down the for sale.

\section{REFERENCES}

Arroyo, G. and Bolanos, R. (1960): "Salmonellosis problem among cattle in Costa Rica". Rev. Biol. Trop., 8, 49-51.

Assiut Vet.Meda. Vol. 22, No. 43, 1989. 
Bailey, W.R. and Scott, G. (1978): "Diagnestic microbiology". A text book for the isolation and identification of pathoginic micro-organisms. The C.V. Mosby Comp. Saint Lois.

R. (1975): "Medical microbiology".

Cruickshank, R.: Duguid, I.; Matming,
12uh Fd. Livingstone, I dinturgh Iondon and New York.

the control campaing against SalmonellosVel. J., 43, 203. w. (1974): "Results of the control campaing against Salment, 81 No.

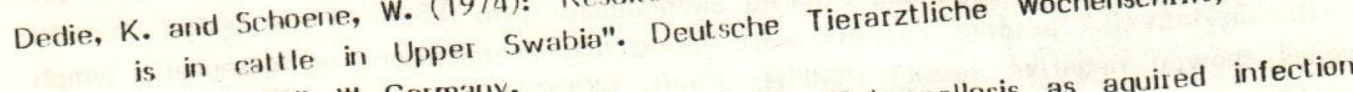
14, 325-329, W. Germany.

Edel, W. Guinee and Kampelmachar, E.H. (1970): Reihe B. 17, 479.

among herd of cattle" Zbl. Vet. Medentification of enterobacteriaceae". 3rd Ed. Burgess publi. Comp.

Heard, M.; Nada, E.; Jennett, B. and Linton, M. (1972): "Changing patter. 364.

excretion in various catlle populations" Vel. Rafmonella infectionsin Cattle feeded on contaminat-

lack, E.J. and Hepper, P.T. (1969): Sami $196-197$. in calves". Verst. Vollksqezontio.,

Kampelmacher, E.H. (1957): "Aquired Salmonellosis in
1957, 1293.

Keulen, G. and Hofstra, K. (1964): "Bovine Salmoellosis" Zble
728. 728.
Miner, J.; Fina, L. and Piatt, C. (1967): "Salmonellosis in cattle: An serolonger Salmo-
ion". Appl. Microbi., 15, 627. nellosis in relation to infection 688.

Nottingham, P.M. and Urselmann, A.J.
calves". N.Z.J. Agric. Res., 4., 449.

Rankin, J.D. and Burrows, M.R. (1970): "Salmonella infection among animals". Brit. Vet. J., 126, 211.

Rankin, J.D. and Taylor, M.J. (1969): "Salmonella infection in cattle reared in yards". Vet. Rec., 85, 578.

Rasch, K. (1957): "Salmonella in faeces of healthy calves". Berl. Munch. Tierarztl. Wschr. 70, 161.

Rothenbacker, H. (1965): "Mortality and morbidity in calves with Salmonellosis". J.A.V. M.A., Vol. 147, No. 11, 1211-1214.

Sharma, V.; Kaura, Y. and Singh, I. (1972): "Salmonella carriers in Indian cattle". Indian J. Med. Rese, 61, 184-187.

Smith, H.W. (1968): "Salmonellosis in calves". Vet. Rec., 83, 15.

Assiut Vet.Med.J. Vol. 22, No. 43, 1989. 


\section{F.A. AHMED, et al.}

Table (1)

Incidence of Salmonella in $\mathbf{4 5 0}$ apparently healthy market calves

\begin{tabular}{lccccc} 
Market & $\begin{array}{l}\text { No. of } \\
\text { samples }\end{array}$ & $\begin{array}{l}\text { No. of } \\
\text { positive } \\
\text { calves }\end{array}$ & Incid. \% & $\begin{array}{l}\text { No. of } \\
\text { diarrh. } \\
\text { calves }\end{array}$ & Incid. \% \\
\hline $\begin{array}{l}\text { H-Maasara } \\
\text { H-Wasta }\end{array}$ & 150 & 3 & 2 & 6 & 50 \\
Manikabad & 150 & 2 & 1.32 & 4 & 50 \\
Iotal & 150 & 1 & 0.67 & 1 & 100 \\
\hline
\end{tabular}

Table (2)

Distribution of salmonella serotypes in the tested 450 market calves

\begin{tabular}{lccl}
\hline Strain & $\begin{array}{c}\text { No. of } \\
\text { isolates }\end{array}$ & Incid. \% & \multicolumn{1}{c}{ Market } \\
\hline Salm.typhi & 1 & 0.22 & El-Maasara \\
\hline Salm.dublin & 2 & 0.44 & Fl-Maasara \& El-Wasta \\
Salm.typhimurium & 1 & 0.22 & E.l-Wasta \\
Totm.enteritidis & 2 & 1.32 & El-Maasara \& Mankabad \\
\hline
\end{tabular}

